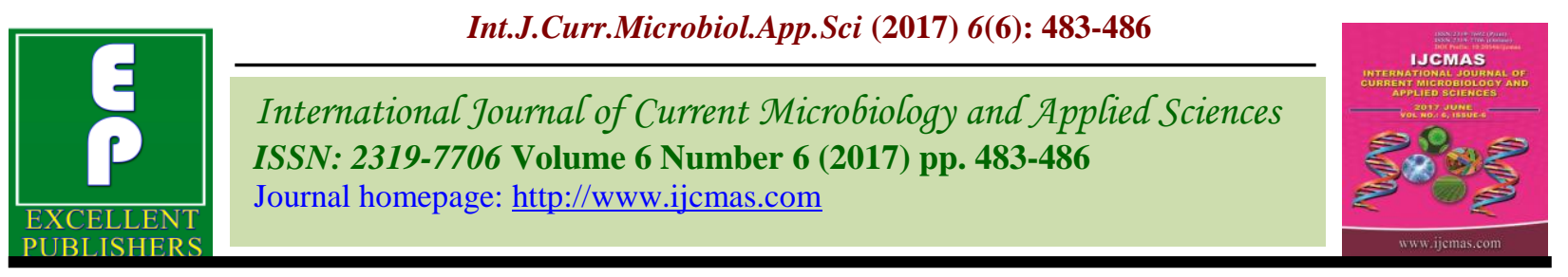

Original Research Article

https://doi.org/10.20546/ijcmas.2017.606.056

\title{
Factors Influencing Stone Weevil (Aubeus himalayanus Voss) Infestation in Indian Jujube
}

\author{
V. Karuppaiah*, Hare Krishna and S.K. Sharma \\ Central Institute for Arid Horticulture, Beechwal, Bikaner Rajasthan, India \\ *Corresponding author
}

\begin{tabular}{|c|c|}
\hline & A B S T R A C T \\
\hline & \multirow{6}{*}{$\begin{array}{l}\text { A study was conducted to evaluate the role of bio-physical traits of ber, } \\
\text { Ziziphus mauritiana fruits on varietal preference of stone weevil Aubeus } \\
\text { himalayanus Voss (Curculionidae: Coleoptera) infestations. Seven popular } \\
\text { Ziziphus varieties was evaluated for their bio-physical traits including fruit } \\
\text { size, fruit shape, average fruit weight, fruit texture and pulp stone ration } \\
\text { (PSR) using standard procedure. Corresponding per cent fruit infestation of } \\
\text { stone weevil also recorded. Results revealed that, bio-physical characters } \\
\text { influences fruit infestation by stone weevil. Among the parameters } \\
\text { estimated, the pulp stone ratio (PSR) found to be most critically influencing } \\
\text { factor for weevil preference for infestation. Of the seven cultivars tested, } \\
\text { CV Banarasi Karaka was relatively less attracted to fruit weevil and it was } \\
\text { attributed due to bio-physical factor, low PSR ratio. This cultivar can be } \\
\text { utilized as a source of resistance to ber stone weevil in ber improvement } \\
\text { programme. }\end{array}$} \\
\hline Keywords & \\
\hline $\begin{array}{l}\text { Stone weevil, } \\
\text { Indian Jujube, } \\
\text { Ziziphus } \\
\text { mauritiana, } \\
\text { Ber germplasm }\end{array}$ & \\
\hline Article Info & \\
\hline $\begin{array}{l}\text { Accepted: } \\
\text { 04 May } 2017 \\
\text { Available Online: } \\
\text { 10 June } 2017\end{array}$ & \\
\hline & \\
\hline
\end{tabular}

\section{Introduction}

The ber (Ziziphus mauritiana Lamarck) also called as desert apple belonging to the family Rhamnaceae. In India, it is a popular dry land fruit crop for arid and semi-arid region of India and most of the cultivated areas are confined to Rajasthan, Haryana, Punjab, Gujarat, Maharashtra and Uttar Pradesh and some extent its cultivation is also done in the states of Tamil Nadu, Andhra Pradesh, Karnataka, Bihar, Chhattisgarh, Madhya Pradesh, Assam and West Bengal states of India. The crop is gaining popularity among the growers because of its adaptability to adverse climatic condition and good returns.
However, the avoidable loss is more due to insect pests and diseases (Singh, 2008). The introduction of improved varieties and irrigation leads unpredictable change in insect pests in this eco-system. In India, more than 130 species of insect pests found to be infested on ber and very few are attained the pest status.

Among the various major pests infesting ber, stone weevil Aubeus himalayanus Voss (Curculionidae: Coleoptera) an emerging pest of Indian Jujube (Balikai et al., 1998; Karuppaiah et al., 2010). The pest causes 
damage up to $43 \%$ and there would be severe fruit drops if infestation occurs at pea to pepple-size of fruit (Karuppaiah, 2015). Chemical insecticides were more effective to manage stone weevil and application of neem based formulation and biological pesticide were also substantially reduce the weevil infestation when sprayed at blooming stage of crop. But it adds to cost of cultivation and also affects the natural enemies as well pollinators in ber eco-system. Use of resistant varieties may be an effective tool for its management. Cultivars resistance in Indian jujube to stone weevil also noticed (Srivastava and Nanda, 1983). However, the role of cultivars traits on stone weevil infestation has not been worked out. In which bio-physical characters of fruit are important parameters which is influences infestation level. This information is vital for initiation improvement programme to develop resistant varieties against this emerging pest. In this context, the present investigation was undertaken to study the cause of variation and to find out the effect of various bio-physical on the extent of stone weevil infestation.

\section{Materials and Methods}

The experiment was conducted at Central Institute for Arid Horticulture, Bikaner, Rajasthan during 2009-14. Seven popular jujube cultivars viz., Gola, Seb, Umran, Banarasi Kadaka, Thar Sevika, Thar Bhubraj were selected for the study. Observations of stone weevil infestation in different cultivars were made at fortnight interval. Three unsprayed randomly selected ber trees of uniform vigour and size were selected and each tree considered as one replication. Three branches of each tree from upper, middle and lower strata of canopy was taken for observation. The total number of fruits and infested fruits from each branch were recorded and per cent infestation was estimated. Naked ovipositors puncture on fruit by adult female was taken as an infestation mark. The other parameters viz were recorded for one season only. The trees under observation were not given any insecticides treatment during this study. The statistical mean comparison was worked out.

Per cent damage $=\frac{\substack{\text { Infested fruits } \\ \text { Total fruits }}}{--------- \text { X } 100}$

The bio-physical parameters viz., fruit size, fruit shape, average fruit weight, fruit texture and pulp stone ration (PSR) was recorded at semi-ripe stage. The fruit size was measured by calculating length (distance between the polar ends) and the breath (equatorial diameter) of 10 random fruits with help of a vernier caliper. Average fruit weight was recorded as mean of the weight of the same fruits observed for fruit size. The pulp stone ratio was calculated by comparing the volume of water displaced by fruits and by their stones as (Singh and Vashitha, 2002).

$\mathrm{PSR}=(\mathrm{Vf}-\mathrm{Vs}) / \mathrm{Vs}$

Whereas PSR, pulp and stone ratio; Vf Volume of water displaced by whole fruits; Vs - Volume of water displaced by stones. The Tukeys mean comparison of damage, fruits and parameters were analyzed using SPSS statistical software.

\section{Results and Discussion}

The cultivars evaluated for stone weevil infestation showed significant difference. The per cent infestation of stone weevil in cultivar Gola, Seb, Umran, Gomakirti, Banarsi Karaka, Thar Sevika and Thar Bhubraj was $21.01,31.07,35.75,21.61,9.34,37.77$ and 27.98, respectively. The cultivar Thar Sevika registered maximum infestation followed by Umran and Banarasi Karaka showed least damage. Other hand, the distinct variation 
also observed among the cultivars evaluated for their fruit bio-physical parameters are present in table 1 . The order of fruit size was Thar Sevika> Thar Bhubraj> Banarasi karaka $>$ Seb > Gola > Gomakirti > Umran.

This is based on the value of fruit diameter plus fruit length. The average fruits weight was $24.36,19.02,17.79,17.82,16.14,17.82$ and $16.58 \mathrm{~g}$ for Gola, Seb, Umran, Gomakirti, Banarsi Karaka, Thar Sevika and Thar Bhubraj, respectively. Gola recorded highest fruit weight followed by the cultivar Seb. The cultivars Umran, Goma kirti and Thar sevika registered more are less similar fruit weight. It shows that fruit weight did not have any relation with fruit weight. In general the cultivars bearing large fruits contracted greater infestation compared to those having smaller size-fruits. It was evident by existence of positive relation $(r=0.479)$ between fruit infestation and fruit-size.

This could be attributed to the availability of sufficient edible material in large fruits, favored the egg laying and affording adequate feeding and survival of the grubs. Further, in this study the cultivars having large fruit size also registered higher proportion of stone and it could be the possible reason for greater incidence. Whereas, fruit weight of different cultivars revealed negative relation $(r=-0.755)$ with stone weevil infestation. This could be because of different in the fruit pulp size, texture and size of the stone inside, which could be vary for different cultivars.

Table.1 Relation between stone weevil infestation and fruit bio-physical parameters of different jujube cultivars

\begin{tabular}{|l|l|l|l|l|l|l|}
\hline Cultivar & $\begin{array}{l}\text { Fruit infestation } \\
(\%)\end{array}$ & $\begin{array}{l}\text { Fruit size* } \\
(\mathrm{cm})\end{array}$ & $\begin{array}{l}\text { Fruit } \\
\text { shape }\end{array}$ & $\begin{array}{l}\text { Avg. fruit } \\
\text { Weight }(\mathrm{g})\end{array}$ & $\begin{array}{l}\text { Fruit } \\
\text { texture }\end{array}$ & $\begin{array}{l}\text { Pulp stone } \\
\text { ratio }\end{array}$ \\
\hline Gola & $21.01(4.57) \mathrm{b}$ & $3.35 \times 3.24$ & Round & $24.36 \mathrm{a}$ & Soft & $0.25 \mathrm{~cd}$ \\
\hline Seb & $31.07(5.57) \mathrm{cd}$ & $2.91 \times 3.81$ & Round & $19.02 \mathrm{~b}$ & Hard & $0.27 \mathrm{c}$ \\
\hline Umran & $35.75(5.98) \mathrm{de}$ & $2.97 \times 3.22$ & Oval & $17.79 \mathrm{c}$ & Hard & $0.31 \mathrm{~b}$ \\
\hline Gomakirti & $21.61(4.64) \mathrm{b}$ & $2.83 \times 3.57$ & Round & $17.82 \mathrm{c}$ & Hard & $0.24 \mathrm{~d}$ \\
\hline $\begin{array}{l}\text { Banarsi } \\
\text { karaka }\end{array}$ & $9.34(3.05) \mathrm{a}$ & $2.63 \times 4.19$ & Oval & $16.14 \mathrm{~d}$ & Soft & $0.22 \mathrm{~d}$ \\
\hline Thar sevika & $37.77(6.14) \mathrm{e}$ & $2.86 \times 4.31$ & Oval & $17.82 \mathrm{c}$ & Fine soft & $0.36 \mathrm{a}$ \\
\hline $\begin{array}{l}\text { Thar } \\
\text { Bhubraj }\end{array}$ & $27.98(5.28) \mathrm{c}$ & $2.70 \times 4.23$ & Oval & $16.58 \mathrm{~d}$ & Soft & $0.34 \mathrm{a}$ \\
\hline
\end{tabular}

Correlation co-efficient (r) between; Infestation $(\%)$ and fruit size $=0.479^{* *}$; Infestation and fruit weight $=-0.755^{* *}$ Infestation and PSR $=0.748^{* *}$

There were 2 distinct fruit shapes, viz. round and oval was observed among ber cultivars. The cultivars Gola, Seb and Gomakirti had round shaped fruits. Among these, cv. Seb had greater weevil infestation followed by Gomakirti and Gola. The cultivars Umran, Banarasi Karaka, Thar Sevika and Thar Bhubraj had oval shaped fruits. In which Thar Sevika registered maximum weevil infestation followed by the Umran and Thar Bhubraj. The least infestation noticed in the $\mathrm{cv}$. Banarasi
Karaka with oval shape fruits. The fruits of the evaluated cultivars exhibited 3 distinct fruit textures viz., hard, soft and fine soft. The cultivars Seb, Umran and Goma Kirti had hard fruit textures; Gola, banarasi Karaka and Thar Bhubraj had soft fruit texture. The cv. Thar Sevika had fine soft fruit texture. The cultivars having fine soft i.e. Thar Sevika recorded maximum stone weevil infestation. However, the cultivar having hard texture also registered greater infestation which was observed in CV 
Seb. The greater damage in the cultivar with oval shaped fruits might be attributed to the stone length and other stone character and fruit texture did not showed any relation with the infestation. The adults preferred to lay egg on the stylar end, newly hatched grubs starts mining from the stylar end and move towards distal end. In such case, the cultivar with sufficient internal seed content possibly attracted more egg laying. However, the parameters of seed coat also need to be investigated since soft seed coat is more favorable for initial entry to the grub.

The relative amount of stone in the fruits of cultivar was $0.25,0.27,0.31,0.24,0.22,0.36$ and 0.34 in Gola, Seb, Umran, Gomakirti, Banarsi Karaka, Thar Sevika and Thar Bhubraj, respectively. Thar Sevika and Thar bhubraj registered relatively greater stone portion; Goma kirti had least PSR. A strong positive correlation $(\mathrm{r}=0.748)$ was observed between fruit infestation and pulp stone ratio. It was little higher than that observed relation between fruit infestation and fruit size $(r=$ 0.479). This may be due to the difference in the size of the stone within the fruit, which is not reflected in fruit size parameter. However, it is accounted for in pulp stone ratio. The positive correlation between fruit size and PSR indicate that PSR is independent of fruit size.

In conclusion, all though various bio-physical characters are associated with the relative damage of stone weevil in ber, the pulp stone ratio is critical factor that would be responsible greater infestation. Among the cultivars evaluated, CV Banarasi karaka relatively less attracted to fruit weevil infestation and it could be utilized as a source of resistance to ber stone weevil in ber improvement programme.

\section{References}

Balikai, R.A., Naik, L.K and Yelshetty, S.1998. A record of ber fruit weevil, Aubeus himalayanus Voss (Curculionidae: Coleoptera) from Karnataka. Karnataka $\mathbf{J}$ of Agric Sci, 11(2): 508.

Karuppaiah, V. 2015. Seasonality and management of stone weevil, Aubeus himalayanus Voss (Curculionidae: Coleoptera): An emerging pest of Indian Jujube (Ziziphus mauritiana L.). African J Agric Res, 10(8): 871-876.

Karuppaiah, V., More, T.A., Sivalingam, P.N., Hanif Khan and Bagle, B.G. 2010. Prevailing insect pest of ber (Ziziphus mauritiana Lamrck) and their natural enemies in hot arid ecosystem. Haryana $\mathbf{J}$ of Hort Sci, 39(3and4): 214-216.

Karuppaiah, V., More, T.A and B.G. Bagle. 2010. A record of stone weevil (Aubeus himalayanus Voss) (Curculionidae: Coleoptera) on ber in hot arid region of Bikaner, Rajasthan. Karnataka J. Agric. Sci., 23(1): 180-181.

Singh, M.P and Vashlshtha. B.B. 2002. Factors influencing infestation of fruit-fly (Carpomyia vesuviana) in Indian jujube (Zizyphus mauritiana). Indian J Agric Sci, 72(9): 543-547.

Singh, M.P. 2008. Managing menace of insect pests on ber. Indian Horti. 53(1):31-32.

Srivastava AK and Nanda US (1983). Studies on the control of insect pest at Udaipur. Technical Document No.13 Second National Workshop on Arid Zone Fruit Research Sukhada University Udaipur, p.288.

\section{How to cite this article:}

Karuppaiah, V., Hare Krishna and Sharma, S.K. 2017. Factors Influencing Stone Weevil (Aubeus himalayanus Voss) Infestation in Indian Jujube. Int.J.Curr.Microbiol.App.Sci. 6(6): 483-486. doi: https://doi.org/10.20546/ijcmas.2017.606.056 